\title{
Free Trade or Protection: A Literature Review on Trade Barriers
}

\author{
Jing Ma (Corresponding author) \\ School of Economics, DUT Faculty of Management and Economics, Dalian 116023, P. R. China \\ School of Economics and Management, Changchun University of Science and Technology \\ Changchun 130022, P. R. China \\ Tel: +86-159-4307-1458Ｅ-mail: majingdoll@hotmail.com
}

Yuduo Lu

Department of Economics, Dalian University of Technology, Dalian 116023, P. R. China

E-mail: luyuduo@163.com

Received: March 14, 2011 Accepted: March 26, 2010 doi:10.5430/rwe.v2n1p69

\begin{abstract}
The purpose of this paper is to, firstly explain the reason of international trade according to recent theories; secondly, collect several sorts of opinions about free trade and protectionism referring to relevant literatures; thirdly describe export barriers in different aspects, such as natural barriers and artificial barriers; lastly from trade regulation perspective introduce WTO as a tool of promoting international trade.
\end{abstract}

Keywords: International Trade, Trade Barriers, Protectionism, WTO

\section{Introduction}

According to a series of theories of international trade and global economy circumstances currently, free trade as one of the essential aims of WTO is the main tendency for international trade development, even though the existing of trade protectionism. Therefore plenty of trade agreements among different countries and regions have led to lower, even no tariff in categories of products' importation and exportation although import and export barriers still exist from the very beginning. Actually nowadays tariff barrier is less important as tariff agreements are rather apparent documentarily, thus no one would like to take this risk to limit importation. So a great deal of more flexible, more implicit non-tariff barriers, which are carried out to protect national industries and products, appeared subsequently.

Through a literature review on trade barriers, we aim to show a theoretical development of arguments on free trade and trade protectionism historically as well as recently. Hopefully, the different perspectives on export barriers can provide scholars in the field with new approaches to the issue, and construct a theoretical foundation for the further research of the authors.

\section{Recent Theories on International Trade}

Today, there are number of theories which seek to explain international trade. First of all, these theories should be considered as descriptive theories to explain trade patterns. What circumstances can explain why one country exports one type of goods and another country another type of goods? An analysis of the theories concerning international trade, leads to the conclusion that there is a natural distinction between traditional theory and recent theory (Søren Kjeldsen-Kragh, 2001).Søren Kjeldsen-Kragh illustrated theories of international trade from both traditional and recent perspectives, and gave a corresponding comparison with respect to them. Recent theories assume that products are differentiated. They no longer assume constant returns to scale. There may be economies of scale and benefits in connection with product specialization at the firm level. Finally, there may be external economies.

\subsection{Economies of Scale}

\subsubsection{Economies of Scale at the Firm Level}

Another major reason that international trade may take place is the existence of economies of scale (also called increasing returns to scale) in production. Economies of scale means that production at a larger scale (more output) can be achieved at a lower cost (i.e. with economies or savings). Trade between countries need not depend upon country differences under the assumption of economies of scale(Steven M. Suranovic , 1999). The average cost is going down 
with the being enlarged scale of manufacturing. This theory can explain the increasing trade between different developing countries, even though they have the same factor proportion advantage, like low labor cost, natural resources and so on.

\subsubsection{Externalities}

In contrast to internal economies of scale within firms, there can also be external economies of scale. There refer to some external advantages associated with a firm being located in an industrial environment. These advantages are called external because they are located outside the firm. And in the cluster industry area new technologies extend more quickly, markets and infrastructures are more mature and run more efficiently. Enterprises benefit from all the above mentioned factors, and obtain more outputs with fewer inputs, thus average production costs go down. So contributions to infrastructure constructing by governments or corresponding organizations is rather important from this perspective.

\subsection{Specialisation}

Products are made in different characteristics to meet the requirements of different markets and customers. Nevertheless differentiated products theory and economies of scale contradict each other. In order to decrease production costs, enlarging production scale is very necessary to manufacture standard products in large quantity, but it conflicts with the former one which needs diversification and small quantity. It is impossible to come to consistency between these two facets. So one of the ways to solve this dilemma is to spread products in the world markets and acquire benefits from trades. Although conceivably a nation might have a sufficient variety of productive factors to produce every kind of good and service, it would not be able to produce each good and service with equal facility. The United States could produce hand-woven rugs, but only at a high cost, since the production of such rugs requires great quantities of labour, which is expensive in this country. The production of hand-woven rugs, however, would afford reasonable employment for the large supply of cheap labour in a country like India. It would be advantageous for the United States, therefore, to specialize in a commodity such as computers, whose production makes use of the abundant supply of technology in this country, and to export computers in exchange for hand-woven rugs from India. This example illustrates in a very simple way the gains that result from international specialization-each nation is able to utilize its productive factors in their most productive combinations. By raising the productivity of national economies, international specialization increases the output of goods and services. This is its economic justification and the principal justification of the international trade that makes possible such specialization (Franklin R.Root, 2000).

\subsection{Competition}

With the tendency of globalization, the similar commodities with different brands can be found all around world. In order to survive themselves, enterprises have to make every effort to create competition advantage and process foreign trade. More and fiercer trade competition becomes one of the reasons of promoting international trade develop around nations and regions. But Price competition deteriorated terms of trade gradually. Also costs advantage has not been transferred into profits advantage (Chen and Zhang, 2002). Non-price competition consists of quality competition, non-quality competition and technique competition (Chen and Zhang, 2002). With the updating of consumption tendency, products will be more advanced and differentiated. Switching from price competition to non-price competition is the fundamental step to implement products differentiation strategy. Non-quality competition includes marketing, services after sale, company image, management, branding and so on.

Traditional theory gives an exact account of the trade pattern. In neo-classical factor proportion theory, the countries' factor endowment explains the trade pattern. According to Ricardo's theory, differences in production conditions, reflected in differences in productivity, determine the pattern of trade. The recent theories which take into account differentiated products, as well as economies of scale and enterprise specialization, succeed in explaining the substantial trade volume, but not the trade pattern.

\section{Free Trade or Protection}

The issue of free trade versus protection has been in dispute since the eighteenth century. The arguments are complex and subtle, although the controversy itself is obviously (Franklin R.Root, 2000).

\subsection{Free Trade advocating}

\subsubsection{Benefits from Free Trade}

In Franklin's case for free trade, he gives a strong argument of the benefits from free trade. The principle of comparative advantage demonstrates that for the world as a whole free trade leads to a higher level of output and income than no trade (autarky). Free trade also enables each nation to obtain a higher level of production and consumption than can be obtained in isolation. Under perfect competition, free trade achieves a worldwide allocation of resources that meets the 
requirements of optimality: It is impossible to make anyone better off (through reallocation) without making someone else worse off. Free trade achieves equality between each country's marginal rate of transformation in production (MRT) and its marginal rate of substitution in consumption (MRS) and the international terms of trade (ITT). In contrast, trade barriers prevent this equilibrium condition by creating divergences between the domestic and international prices of tradable goods. Hence, under protection, MRT=MRS $\neq \mathrm{ITT}$. It follows, therefore, that trade barriers cause a suboptimal allocation of the world's factors of production and a lower world real income than would exist under free trade. Thompson Henry analyzes the results by trade protectionism from different stakeholders such as government, firms, employees and consumers. Protectionism redistributes income. Protection of an industry creates gains for some and losses for others. Those who enjoy the gains can be expected to favour protection. Government protection of domestic industry from foreign competition began the debate on free trade and the effects of economic policy which led to the study of economics. International economists have consistently advocated openly facing international competition with a policy of free trade. Both theory and evidence suggest that income rises and is more evenly distributed when countries pursue free trade. Comparative advantage is the foundation of international trade and one of the most universal principles in science. Nations, firms, or individuals that ignore their comparative advantage will be less efficient and ultimately not as well off as with specialization and trade. Protectionism restricts the ultimate beneficial effects of exploiting comparative advantage through free trade. Protectionism restricts international trade, lowering national income and distributing income more unevenly. Economists have yet to persuade governments to give up protectionism. Tariffs, quotas, and other non-tariff barriers on imports are common government policy. The ultimate reason for protectionism is simple. Those who benefit from the policy, the owners and workers in the protected industry, are organized and willing to spend resources to lobby and influence political decisions. Disorganized consumers and taxpayers do not generally realize the extent of their losses with tariffs. The amount of the loss for each individual consumer is not large enough to spend resources lobbying against the harmful policy. The benefits of protectionism are concentrated but costs are thinly spread. The overall inefficiency of protectionism prevails (Thompson, Henry, 2000).

\subsubsection{Extending market abroad}

As most nations and regions continue to become more involved in the world economy, it is critical that the states, in their economic development efforts, explore the foreign trade structure of their economies to obtain a clearer understanding of where their industrial comparative advantages lie. With this knowledge, a state will be able to maximize the benefits of foreign trade as it more efficiently targets its limited economic development resources. From LeaAnn Stagg's point of view, (Cavusgil and Czinkota, 2001) from any one state's perspective, exporting to a foreign country or 'exporting' to another state represents equally good ways of generating new wealth. That is, both bring in additional income not otherwise possible had the state served a local market alone. To the extent that states rely on domestic trade to generate new wealth, however, one state's gains often come at the expense of another. By reaching new markets, states can actually increase the economic pie, rather than merely compete with each other for existing markets.

\subsubsection{The National Gains from International Trade}

Trade has played a vital role in the development of most economies. Trade is an engine of growth. The contribution of international trade is so immense that few countries could become self-sufficient even with the greatest effort. Contemporary economies have been shaped by the international trade and specialization of the past, and their continued viability is closely dependent on the world economy. Franklin gives an example of international trade between UK and Japan. It is physically impossible for the United Kingdom or Japan to feed, clothe, and house their present populations at their current levels without import from other countries. Economic self-sufficiency for these two nations would mean poverty standards of living unless emigration proved possible on a very large scale. The survival of these countries depends essentially on the export of manufactures that require little space to produce in exchange for foodstuffs and raw materials that require great space to produce or are found in only certain areas of the earth. (Franklin R.Root, 2000) The United Kingdom and Japan are examples of high dependence on international trade. But even countries that are able to supply their own peoples with the basic necessities of life out of domestic production would be faced with an unbearable decline in living standards if they were cut off from international trade. (Much of the decline in living standards during a war is due to the cessation of international trade, as illustrated by the experience of neutral countries such as Sweden and Switzerland during World War II) Manufacturing industries would also face many difficulties. Without imports, many raw materials would no longer be available and inferior substitutes would replace them. Domestic supplies of other raw materials would no longer be supplemented by imports, and their prices would rise to increase costs of production all along the line. The loss of export markets would also cause severe dislocations in many manufacturing industries. 


\subsubsection{International Trade's Competitive effects}

International trade's competitive effects generally benefit both global economic welfare and individual liberty. That is generally true of international trade's effects, including reduction of the scope or bite of international regulation: trade-induced changes in such regulation most often will enhance international welfare by allowing increased competition and diminishing economic rents protected by regulatory intervention. While trade can produce a diminution of international welfare in some instances, where trade undermines the ability of a nation to deal with certain negative externalities of production, but this will be the exceptional case. Trade's tendency to diminish regulatory rents will be inimical to the interests of many politicians and politically influential groups, which will face higher costs to maintaining favored regulatory policies. These individuals and groups have incentives to argue that particular instances of open trade fit the limited circumstances in which trade reduces national economic welfare. For instance, infant industries were strongly protected by many governments in order to achieve rapid industrial growth. Someone will claim as well that trade reduces the ability of national polities to design regulation favored by each nation's citizens. If all processes governing regulation in the absence of trade are taken as part of the calculus of what a nation's citizen's favor, this claim is a tautology. If, however, citizens' views are abstracted from current political-decisional processes, trade is seen to serve (under most conditions) to counteract antidemocratic tendencies in domestic governance, protecting individual liberty in a world of diverse tastes. (Cass and Haring, 2000)

\subsection{Trade Protectionism}

It is much more difficult to find the theories or scholars advocating trade protectionism through literature reviews compared to free trade. But there are still several arguments for protection, such as national security, infant industry, and diversification analyzed by Franklin.

\subsubsection{National Security Argument}

One of the reasons to protect national industry is the need to maintain an 'adequate' national defence. Even Adam Smith, the venerable father of free trade, wrote in 1776 that 'defence is much more important than opulence' (Adam Smith, 1937). The problem lies in defining the specific requirements of national defence and the proper way to meet those requirements. Otherwise the national security argument may be used to justify complete self-sufficiency or the protection of any industry. Since most producers consider their activities essential to the defence of their country, the national security argument is particularly subject to abuse.

\subsubsection{Infant Industry Argument}

In its traditional form, the infant industry argument asserts that a new industry which has a potential comparative advantage may not get started in a country unless it is given temporary protection against foreign competition. Most often, the argument stresses the necessity of protected domestic markets that will offer an opportunity for economies of scale in production. Protection would enable local manufacturers to get competitive with foreign manufacturers who already enjoy economies of scale. Aside from economies of scale, protection would also afford local producers the time to improve their skills in management, production, marketing, and the application of technology. Once competitive strength was built up, protection would be abandoned for free trade.

\subsubsection{Diversification Argument}

The diversification argument for protection is actually two arguments that commonly masquerade as one. One argument urges import protection as a means to bring about a diversification of exports so as to lessen instability in export income. The second argument proposes import protection as a means to achieve diversification in the domestic economy and thereby promote economic growth. Both arguments are put forth mainly by representatives of the non-industrial, developing nations.

The diversification-for-export-stability argument proceeds from the dependence of many developing countries on one or two agricultural or mineral products for most of their export income. This 'over-specialization' makes such countries highly sensitive to supply or demand shifts in a single export product. Furthermore, it is widely accepted that primary commodities experience wide cyclical fluctuations in price because of low price elasticity of supply and demand. In this context, therefore, the export stability argument becomes and argument for the substitution of manufactured exports for primary exports via import protection that fosters the development of domestic industry.

Theoretically, the diversification-for-export-stability argument derives its validity from a possible divergence of private and social values in a world of change and uncertainty. When private costs do not fully reflect social costs, then the gains from higher economic efficiency may be more than offset by long-run losses due to economic disruptions caused by dependence on foreign markets. The policy application of this argument, however, is fraught with difficulties, notably 
the problem of choosing the proper diversification mix and the means to achieve it. These difficulties tend to make import protection and ineffective policy tool compared with export subsidies and other measures of direct export promotion. Indeed, protection has a qualified validity only when export diversification requires the prior development of new industries to produce goods that are presently being imported by the country in question. Thus, the diversification-for-export-stability argument for protection is really a version of the infant industry argument that emphasizes export stability rather than economies of scale.

The diversification-for-domestic-growth argument rests upon the doctrine of 'balanced' economic growth, which asserts the necessity for a simultaneous or parallel development of all industries throughout the economy. This argument, therefore, may be used to justify a policy of general import substitution that cuts across all categories of industrial products. Lacking the specific criteria of the traditional infant industry argument, the diversification-for-domestic-growth argument lends itself to easy abuse by protectionist. At its extreme, it closely resembles the argument for autarky in its real consequences.

\section{Barriers to Exportation}

\subsection{Management Perspective}

An important reason for advocating the simultaneous examination of export barriers is that they are very highly correlated (Bauer Schmidt, Sullivan, and Gillespie 1985). Another reason is to understand the structure of perceived barriers using a decision-process framework. In this framework, export entry or expansion behaviour is the result of a strategic choice by the firm (Reid 1982). The barriers become functionally salient only after they are perceived by decision makers (Widersheim-Paul, Olson, and Welch 1978). Particularly for small and medium-sized firms that are likely to have simple decision structures (Mintz 1967; Miller and Friesen 1980), the perceptions of the decision maker dominate the mere existence of these barriers.

The theory of bounded rationality (March and Simon 1958) postulates that decisions are most often made based on limited information. Perceived barriers to exporting reflect the filtered view of individual decision makers in the firm. Therefore the same barriers can be perceived differently by decision makers depending on their relative backgrounds. In a dynamic sense, perceptions can change through experience and by external assistance. Some barriers can be easily overcome through planning (Glover 1983), whereas others may change over a long period. The degree of difficulty of change may vary according to the adaptive capacity of the firm, the firm's experience and knowledge, and the environment. (Cavusgil and Czinkota, 2001)

Export Knowledge. Yair Aharoni (1966) was one of the pioneers in examining the concept of export barriers. He stated that barriers related to market knowledge impact the export commitment decision of firms. Other researchers followed by identifying difficulties associated with locating foreign opportunities and markets (Alexandriedes 1971; Pavord and Bogart 1975; Bilkey and Tesar 1977; Ogram 1982; Tesar and Tarleton 1982).

Another type of knowledge barrier identified by the above researchers relates to market planning and tactics. Smaller firms not only are unaware of the potential benefits of exporting but also are less confident about their ability to plan for exporting. Johanson and Vahlne (1977) called this the 'general knowledge about exporting.' This relates to factors such as knowledge of competition and channels of distribution, payment conditions, transferability of money, and types of export assistance available.

The above two types of barriers reflect management's orientation toward foreign markets. In the issue of Business Week (1988), Stephen S. Cohen, director of the Berkeley Roundtable on the International Economy, stated that outside of a few cases (such as Boeing and Caterpillar, who have very different export mind-sets), very few U.S. companies have the experience and knowledge 'threshold fear' that Bilkey and Tesar (1977) and Michael Czinkota (1982) used to describe export commitment.

\subsection{Languages and Customs Perspective}

Most nations have a distinctive linguistic and cultural identity in addition to a basic political identity. But in Franklin R. Root's opinion, this is not always true, for example the nations that have more than one official language and more than one cultural group in their populations. Moreover, several nations may share a common language and a common cultural heritage. Nevertheless, it is true that people tend to be like each other in more ways when they belong to the same nation than when they belong to different nations. Hence, international trade, unlike most interregional trade with nations, involve persons of different languages, customs, attitudes, values, and other cultural traits. Although such differences do not affect the basic economic similarity between interregional and international trade, they do complicate relations between governments and introduce many new elements into the conduct of international business enterprise (Root, 2000). 


\subsection{Government Influence Perspective}

The policy instruments used by governments could have nature and economic effects to the flows of goods and services in the world economy. The traditional policy instrument is the import tariff. But government also resort to a bewildering variety of measures to restrict imports or subsidize exports. These measures are collectively designated as non-tariff trade barriers (Root, 2000).

\subsubsection{Tariffs Trade Barriers}

Tariffs may be designed to collect revenue for the government or to protect domestic industries against foreign competition(Root, 2000).In order to perform revenue function better, governments have to set the tariffs rates on proper level (not too high actually) to maximize tariffs revenue. Thus import tariffs applied by this purpose can not be regarded as tariff barriers. As tools of national economics policy designed to regulate the international trade of a nation, normal tariffs collections are commonly acceptable methods also, especially in previous industries age. Actually only those extremely high and additional import tariffs as quantitative measures of restriction are the real tariffs barriers, i.e. surcharges with emergency, short-lived character. That is the real protection function of the tariff. But Franklin contends it depends on a partial or complete restriction of imports. When complete protection is desired, a given duty must be high enough to cover the difference in the marginal cost of production between domestic and all foreign producers, including transportation and incidental expenses of importing. If the tariff is to be only partially protective, however, the duty must remain below this difference. When partial protection is desired, goods will continue to be imported, but they will be imported in smaller quantities and the government will collect customs duties. Therefore, the protection function - like the revenue function — will usually afford both protection and revenue, although its purpose is primarily one of protection.

\subsubsection{Non-Tariff Trade Barriers}

As the industrial countries have progressively cut tariff rates under the auspices of the GATT and WTO, non-tariff trade barriers have become more and more prominent, and are used more generally and frequently.

\section{Import Quotas}

Quantitative measures of restriction, like tariff, are tools of national economic policy designed to regulate the international trade of a nation. Unlike tariffs, however, they impose absolute limitations upon foreign trade and inhibit market responses; this makes them extremely effective. Quantitative restrictions ordinarily take the form of import quotas that are administered by the issuance of import licenses to individual traders. Import quotas are applied in three major types throughout the world, i.e. unilateral quotas, negotiated bilateral or multilateral quotas, and tariff quotas. Import quotas are commonly regarded as restrictions on quantities, which are more efficient to limit importations. However international trade disputes rose more easily due to frequent applying this tool of trade protection.

\section{Anti-Dumping}

According to the 'Agreement on implementation of Article VI of the General Agreement on Tariffs and Trade 1994' dumping exists 'if the export price of the product exported from one country to another is less than the comparable price, in the ordinary course of trade, for the product when destined for consumption in the exporting country.'(Jepma and Rhoen, 2002) Franklin describes dumping like, the practice of selling a product in one national market at a lower price than that for which it is sold in another national market. Dumping, therefore, is price discrimination between national markets. Although persistent dumping benefits the importing country by improving its terms of trade, governments consider all forms of dumping by foreign producers to be bad. Consequently, many governments have anti-dumping regulations that usually involve a remedial or punitive anti-dumping duty. It is widely recognized that anti-dumping regulations can easily be used for protection against foreign competition. Dumping and anti-dumping have already been significantly global issues in recent years. As a type of legal tool to maintain impartial trade within the framework of WTO anti-dumping is frequently applied by many countries to protect domestic industries and markets. From economics perspective, when import country and export country have similar factor proportion, the competition advantage on trade mainly depends on economies of scale, products differentiation and market structure (Yao, 1999).Due to the imbalance in developing industrialization, some developing countries with the same factor proportion import the products characterized with economies of scale and uniqueness, meanwhile the disputes on anti-dumping are more and more intense.

\section{Subsidies}

Many national governments, anxious to promote certain domestic industries, pay subsidies to domestic producers or exporters. Subsidies may be extended in the form of outright cash disbursements, tax exemptions, preferential exchange 
rates, governmental contracts with special privileges, or some other favourable treatment. The granting of subsidies results in a cost advantage to the recipient, so they are an indirect form of protection. Subsidized products that move in international trade tend to nullify the protective effect of a tariff in the importing country. To reinstate the intended level of protection, the importing country may impose, in addition to the regular tariff duties, a special surtax or countervailing duty, which is generally equal to the amount of the foreign subsidy. In this matter, the landed cost to the domestic importer is raised by the amount of the subsidy granted to the foreign producer or exporter by the foreign government.

\section{Technical Standards and Health Regulations}

Governments apply many regulations to imports with respect to safety, health, marketing, labelling, packaging, and technical standards. Although generally desirable on social grounds, such regulations may discriminate against imports by imposing greater hardships on foreign than on domestic producers. Because of the increasing technical nature of products, rising living standards, and social pressures, a continuing proliferation of technical and health regulations are expected.

The above mentioned are several frequently used typical non-tariff barriers, furthermore, new non-tariff barriers are continually created as governments respond to changing circumstances.

\section{International Trade Promotion by WTO}

The World Trade Organization (WTO) is the only global international organization dealing with the rules of trade between nations. At its heart are the WTO agreements, negotiated and signed by the bulk of the world's trading nations and ratified in their parliaments. The goal is to help producers of goods and services, exporters, and importers conduct their business. The result is assurance. Consumers and producers know that they can enjoy secure supplies and greater choice of the finished products, components, raw materials and services that they use. Producers and exporters know that foreign markets will remain open to them.

The result is also a more prosperous, peaceful and accountable economic world. Virtually all decisions in the WTO are taken by consensus among all member countries and they are ratified by members' parliaments. Trade friction is channeled into the WTO's dispute settlement process where the focus is on interpreting agreements and commitments, and how to ensure that countries' trade policies conform to them. That way, the risk of disputes spilling over into political or military conflict is reduced. By lowering trade barriers, the WTO's system also breaks down other barriers between peoples and nations. At the heart of the system - known as the multilateral trading system — are the WTO's agreements, negotiated and signed by a large majority of the world's trading nations, and ratified in their parliaments. These agreements are the legal ground-rules for international commerce. Essentially, they are contracts, guaranteeing member countries important trade rights. They also bind governments to keep their trade policies within agreed limits to everybody's benefit.

The agreements were negotiated and signed by governments. But their purpose is to help producers of goods and services, exporters, and importers conduct their business. The goal is to improve the welfare of the peoples of the member countries (www.wto.org).

\section{Conclusion}

Although free trade is commonly accepted as the main tendency of international trade development in most of facets, trade protections are still supported by some stakeholders due to the necessity in particular period or regions. Barriers to exportation consist of several aspects. Language and customs barriers exist naturally but it does not mean it is impossible to overcome. Tariff barriers are less and less important due to several-round hard negotiations on GATT and the following WTO as well. However non-tariff barriers should not be ignored anyway which have been becoming more effective subsequently, especially in the main industrial countries. Countermeasures to these problems by many nations, especially developing countries, are being proposed one after another. WTO has been making every effort to promote international trade and solve trade disputes for one decade as subsequence of GATT. Nevertheless it is still far away from world trade court due to many complicated reasons. But all kinds of trade agreements between countries and regions have played important role in international trade development. 


\section{References}

Bernard A. Gelb. (2001). Textile and Apparel Trade Issues. Congressional Research Service Report for Congress. RS20436. pp2.

Caifa Song. (2004). WTO regulations and China textiles and clothing brand protection. South-West National University. Chengdu. China.

Cass, Deborah. (2003). China and the World Trading System: Entering the New Millennium. West Nyack. NY. USA: Cambridge University Press. doi:10.1017/CBO9780511494482, http://dx.doi.org/10.1017/CBO9780511494482

Catrinus Jepma and Andre Rhoen. (2002). International trade: a business perspective. Open University of the Netherlands Heerlen.

Franklin R. Root. (2000). International Trade and Investment. Seventh edition. The Wharton School University of Pennsylvania. South-Western Publishing Co.

Franklin R.Root. (2000). International Trade and Investment. Seventh Edition. The Wharton School University of Pennsylvania.

Jiagui Chen and Chang Zhang. (2002). Profit advantage-Comparisons of Sino-US competitive industries. International Trade. Vol 5.

Peter Kilduff. (1998). an Overview of the Competitive Dynamics of the Global Textile and Apparel Industries. University of Leeds. Textile Intelligence Center.

S. Tamer Cavusgil and Michael R. Czinkota. (2001). International Perspectives on Trade Promotion and Assistance. Quorum books.

Søren Kjeldsen-Kragh. (2001). International Trade Policy. Copenhagen Business School Press.

Steven M. Subatomic. (1999). International Trade Theory and Policy.

Thompson, Henry. (2000). International Economics: Global Markets \& International Competition. River Edge, NJ, USA: World Scientific Publishing Company, Incorporated. pp111.

Ting Li. (2003). ATC and anti-dumping issues in Chinese textile trade. Dong Hua University Journals. Social Science. Weimin Hao and Qiang Gu. (2003). International competition environment for textiles industry and countermeasures. International Economy Cooperation. Beijing. Pp14-17.

Yao Shen. (1999). Economics Analysis on dumping and anti-dumping. Hang Zhou. Zhejiang University Publication House. Pp177-124.

Yonghui Xu. (2003). The changing of international textiles \& clothing market and the countermeasures of China's textiles industry. Social Science Fronter. Changchun. Pp27-33.

\section{Website Resources}

http://www.investorwords.com

http://www.wto.org 